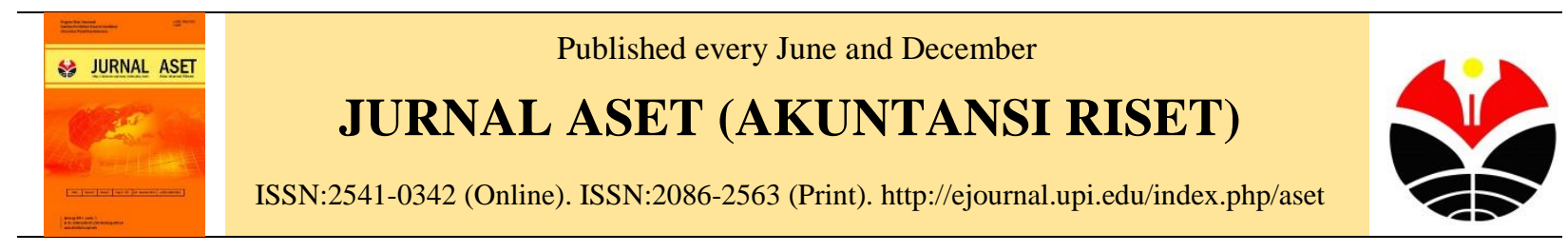

\title{
Pengendalian Internal Terhadap Kecurangan
}

\author{
Sukadwilinda $^{1}$, R. Aryanti Ratnawati ${ }^{2}$ \\ Program Studi Akuntansi, Fakultas Ekonomi, Universitas Sangga Buana \\ Kota Bandung, Jawa Barat, Indonesia
}

\begin{abstract}
Internal control in a company is very important. It is expected that with good internal control, employees do not do things outside the rules that have been set. Today very rarely found companies that are free from fraud. With good internal control is expected to prevent the occurrence of acts of fraud in the company. Fraud is often done is cash fraud. The results of this study indicate that the variable Internal Control $(X)$ has a significant influence on Fraud Cash (Y). This is evident from the constant value of 1.860 and the value of the Internal Control Coefficient (X) of 0.640, this shows that if the Internal Control $(X)$ rises by one point then the variable Prevention of Fraud Cash $(Y)$ will rise by 0.640. Correlation value obtained for 0.776 which means there is a strong correlation relationship between internal control with fraud prevention cash. Internal Control has an effect of $60.2 \%$ on fraud; while the remaining $39.8 \%$ is influenced by other variables that are not examined
\end{abstract}

Keywords: internal control; fraud

Abstrak. Pengendalian internal di suatu perusahaan adalah hal yang sangat penting. Diharapkan dengan pengendalian internal yang baik, karyawan tidak melakukan hal diluar aturan yang sudah ditetapkan. Dewasa ini sangat jarang ditemukan perusahaan yang terbebas dari kecurangan (fraud). Dengan adanya pengendalian internal yang baik maka diharapkan dapat mencegah terjadinya tindakan kecurangan (fraud) di perusahaan. Tindak kecurangan (fraud) yang sering dilakukan adalah kecurangan (fraud) kas. Hasil penelitian ini menunjukkan bahwa variabel Pengendalian Internal (X) memiliki pengaruh signifikan terhadap Pencegahan Kecurangan (Fraud) Kas (Y). Hal ini terbukti dari nilai konstanta sebesar 1,860 dan nilai koefisien Pengendalian Internal (X) sebesar 0,640, ini menunjukan bahwa jika Pengendalian Internal $(\mathrm{X})$ naik sebesar satu poin maka variabel Pencegahan Kecurangan (Fraud) Kas (Y) akan naik sebesar 0,640. Nilai korelasi yang diperoleh sebesar 0,776 yang berarti terdapat hubungan korelasi yang kuat antara pengendalian internal dengan pencegahan kecurangan (fraud) kas. Pengendalian Internal memberikan pengaruh sebesar 60,2\% terhadap kecurangan; sedangkan sisanya sebesar $39,8 \%$ dipengaruhi oleh variabel lain yang tidak diteliti.

Kata Kunci: pengendalian internal; kecurangan

Corresponding author. sukadwilinda@gmail.com, aryanti.ratnawati@yahoo.com

How to cite this article. Sukadwilinda, R Aryanti Ratnawati (2013). Pengendalian Internal Terhadap Kecurangan Jurnal ASET (Akuntansi Riset). Program Studi Akuntansi. Fakultas Pendidikan Ekonomi dan Bisnis Universitas Pendidikan Indonesia, 5 (1),11-21

History of article. Received: Januari 2013, Revision: Maret 2013, Published: Juni 2013 


\section{PENDAHULUAN}

Pada masa sekarang Bank memegang peran penting, karena jika dilihat dari kondisi masyarakat sekarang hampir semua orang berkaitan dengan lembaga keuangan. Menurut Undang-Undang Republik Indonesia Nomor 10 Tahun 1998 tentang "Perubahan UndangUndang No. 7 Tahun 1992 tentang perbankan", yaitu : "Bank adalah Badan usaha yang menghimpun dana dari masyarakat dalam bentuk simpanan dan menyalurkannya kepada masyarakat dalam bentuk kredit dan atau bentukbentuk lainnya dalam rangka meningkatkan taraf hidup rakyat banyak.". Mentaati peraturan dan tidak melakukan kesalahan yang dapat menyebabkan terjadinya penyimpangan dan kecurangan adalah salah satu cara untuk mendapatkan simpati baik dari nasabah ataupun non nasabah.

Kecurangan atau Fraud harus dibedakan dengan kesalahan. Kesalahan dapat diartikan sebagai "Unintentional Mistakes" (kesalahan yang tidak disengaja). Untuk kesalahan yang disengaja berarti bisa dikatakan tindakan fraud. Kecurangan atau Fraud yang dilakukan dapat memberikan dampak negatif di mata masyarakat pada Bank tersebut. Kecurangan umumnya terjadi karena tekanan untuk melakukan penyelewengan untuk memanfaatkan kesempatan yang ada.

Kecurangan atau Fraud bisa dilakukan dengan berbagai cara, kecurangan dengan cara menyiasati sistem adalah hal yang paling sering terjadi. Tindakan ini sering dilakukan untuk mendapatkan keuntungan bagi suatu organisasi yang dilakukan baik oleh orang dalam maupun luar organisasi tersebut. Namun kecurangan atau fraud sering kali dilakukan oleh sumber daya manusia yang ada dalam suatu perusahaan tersebut sehingga berdampak dapat merugikan perusahaan tersebut. Dengan demikian, bank kerap mengalami dilema menghadapi permasalahan yang melibatkan unsur orang dalam sehingga pengendalian internal dinilai harus benar-benar diperkuat

Tindakan kecurangan (fraud) merupakan penipuan yang sengaja dilakukan oleh seseorang atau sekelompok orang sehingga menimbulkan kerugian tanpa disadari oleh pihak yang dirugikan tersebut dan memberikan keuntungan bagi pelaku kecurangan. Kecurangan umumnya terjadi karena tiga hal utama, yaitu : adanya tekanan untuk melakukan penyelewangan, adanya kesempatan yang bisa di manfaatkan serta adanya pembenaran terhadap tindakan tersebut. (Jerry L. Turner, Theodore J. Mock, dan Rajendra P. Srivasta 2003:16). Kejahatan perbankan atau fraud banking merupakan kejahatan yang dilakukan terkait dengan industri perbankan. Jos Luhukay, pengamat Perbankan Strategic Indonesia, mengatakan, modus kejahatan perbankan bukan hanya soal penipuan (fraud), tetapi lemahnya pengawasan internal control bank terhadap sumber daya manusia juga menjadi titik celah kejahatan perbankan.(Kompas.com: Selasa 3 Mei 2011:09.44 WIB)

Tindakan kecurangan (fraud) yang sering terjadi dalam dunia perbankan adalah tindakan kecurangan (fraud) kas. Tindakan kecurangan (fraud) kas memiliki efek terhadap risiko kerugian keuangan karena perusahaan yang terlibat dalam kecurangan sering mengalami kebangkrutan, delisting dari bursa efek, atau melakukan penjualan asset yang material dengan tingkat yang 
jauh lebih tinggi daripada perusahaan yang tidak terlibat kecurangan, sehingga perusahaan harus melakukan tindakan preventif untuk mengantisipasi terjadinya kecurangan dalam perusahaan.

Mencegah tindakan kecurangan (fraud), Bank harus memiliki pengendalian internal yang kuat. Pengendalian internal dapat didefinisikan sebagai suatu proses, yang dipengaruhi oleh sumber daya manusia dan sistem teknologi informasi, yang dirancang untuk membantu organisasi mencapai suatu tujuan atau objektif tertentu. Pengendalian internal merupakan suatu cara untuk mengarahkan, megawasi dan megukur sumber daya suatu organisasi. Selain itu berperan penting untuk mencegah dan mendeteksi terjadinya fraud

Beberapa permasalahan yang dapat diuraikan berkaitan dengan latar belakang adalah : Sejauh mana pengaruh pengendalian internal terhadap pencegahan kecurangan (fraud) kas di PT. Bank Mandiri (Persero), Tbk Area Asia Afrika Bandung.

\section{KAJIAN LITERATUR}

Azhar (2008 : 95) Pengendalian Internal:

"Sebagai suatu proses yang dipengaruhi oleh dewan direksi, manajemen dan karyawan yang dirancang untuk memberikan jaminan yang meyakinkan bahwa tujuan organisasi akan dapat dicapai melalui: efisiensi dan efektifitas operasi, penyajian laporan keuangan yang dapat dipercaya, ketaatan terhadap undang-undang dan aturan yang berlaku."

Sedangkan menurut Krismiajai (2002 : 218) Pengendalian Internal :
"Rencana organisasi dan metode yang digunakan untuk menjaga atau melindungi aktiva, menghasilkan informasi yang akurat dan dapat dipercaya, memperbaiki efisiensi, dan untuk mendorong ditaatinya kebijakan manajemen." Indikator pengendalian internal menurut Valery G. Kumaat (2010 : 16) :

1. Lingkungan Pengendalian

2. Penilaian Risiko

3. Prosedur Pengendalian

4. Pemantauan

5. Informasi dan Komunikasi.

Tindak fraud adalah "manusia" dengan berbagai aasan dari dalam dirinya untuk melakukan tindakan tercela (Kumaat, 2011 : 135). Adapun pengertian kecurangan (fraud) menurut BPKP (2008 : 11) adalah sebagai berikut:

"Dalam istilah sehari-hari, fraud dimaknai sebagai ketidakjujuran. Dalam terminologi awam fraud lebih ditekankan pada aktivitas penyimpangan perilaku yang berkaitan dengan konsekuensi hukum seperti penggelapan, pencurian dengan tipu muslihat, fraud pelaporan keuangan, korupsi, kolusi, nepotisme, penyuapan, penyalahgunaan wewenang dan lainlain."

Indikator pencegahan kecurangan (fraud) Pusdiklatwas BPKP (2008 : 38) adalah :

1. Menetapkan tone at the top

2. Tanggungjawab manajemen untuk mengevaluasi pencegaahn fraud

3. Pengawasan oleh Komite Audit

\section{METODOLOGI PENELITIAN}

Menurut Sugiyono (2006) mengartikan metode penelitian adalah : 
"Cara ilmiah yang digunakan untuk mendapatkan data yang objektif, valid dan reliabel dengan tujuan dapat ditemukan, dibuktikan dan dikembangkan suatu pengetahuan, sehingga dapat digunakan untuk memahami, memecahkan dan mengantisipasi masalah."

Dalam penelitian ini peneliti menggunakan metode survey :

"Penelitian yang dilakukan pada populasi besar maupun kecil, tetapi data yang dipelajari adalah dari dara sampel yang diambil dari populasi tersebut, sehingga ditemukan kejadian-kejadian relatif, distributif, dab hubunganhubungan antara variabel sosiologis maupun psikologis." Sugiyono (2006 : 7)

Penelitian survey memiliki dua cara, yaitu kuesioner (pertanyaan tertulis) dan wawancara (pertanyaan lisan). Menurut Sugiyono (2008 : 199) yang dimaksud dengan kuesioner adalah : "Kuesioner merupakan teknik pengumpulan data yang dilakukan dengan cara meberi seperangkat pertanyaan atau penyataan tertulis kepada responden untuk dijawab."

wawancara adalah : teknik pengumpulan data yang digunakan apabila pelneliti ingin melakukan studi pendahuluan untuk menemukan permasalahan yang diteliti, dan juga apabila peneliti ingin mengetahui halhal dari responden yang lebih mendalam dan jumlah respondennya sedikit atau kecil.” Sugiyono (2008 : 194)

Dalam Penelitian ini juga digunakan metode Asosiatif, metode yang mencari ada tidaknya hubungan secara signifikan antara dua variabel atau lebih. Sugiyono, (2008 : 55)

Sedangkan instrumen penelitian dalam penelitian ini ah menggunakan kuesioner; mengingat data yang diharapkan berupa data primer berbentuk ordinal. Karena data yang diperoleh berbentuk ordinal, maka dalam penelitian ini menggunakan Skala Likert. Skala Likert adalah skala yang didasarkan pada ranking yang diurut dari jenjang yang lebih tinggi sampai jenjang terendah atau sebaliknya (Ridwan dan Akdon 2007:12). Variabel dalam penelitian ini memiliki indikatorindikator yang dibuat menjadi sebuah pertanyaan-pertanyaan untuk responden perusahaan.

Teknik pengujian instrumen data dalam penelitian ini menggunakan uji validitas dan reabilitas. Validitas menurut Saworno, (2008 : 218) adalah suatu skala pengukuran dikatakan valid apabila skala tersebut digunakan untuk mengukur apa yang seharusnya diukur. Contohnya skala nominal yang bersifat non parametik digunakan untuk mengukur variabel nominal, bukan untuk mengukur variabel internal yang bersifat parametik.". Sedangkan Uji Reliabilitas menurut Sugiono (2008 :172) , realibilitas digunakan untuk mengetahui apakah alat pengumpulan data menunjukan tingkat ketepatan, tingkat keakuratan, kestabilan adatau konsisten dalam mengungkapkan gejala tertentu."

Rancangan Analisis dalam penelitian ini dikelompokkan menjadi 2 (dua) bagian yaitu, analisis kualitatif dan analisis kuantitatif.

Analisis Kualitatif : yaitu analisis statistik yang digunakan untuk menganalisa data dengan cara menggambarkan data yang telah terkumpul, tanpa bermaksud membuat kesimpulan yang berlaku untuk umum atau generalisasi.

$$
\text { Langkah-langkah yang }
$$
dilakukan dalam melakukan analisis deskriptif atau kualitatif, yaitu : 
1. Setiap indikator atau subvariabel yang dinilai oleh responden, diklasifikasikan kedalam lima alternatif jawaban dengan menggunakan skala ordinal sehingga menghasilkan peringkat pada jawaban yang ada. Peringkat jawaban setiap indikator diberi skor antara 1 sampai 5.

2. Dihitung total skor setiap variabel atau subvariabel $=$ jumlah skor dari seluruh skor indikator variabel untuk semua responden.

3. Dihitung skor setiap variabel atau subvariabel $=$ rata-rata dari total skor.

4. Deskripsikan jawaban responden dengan menggunakan statistik deskriptif seperti distribusi frekuensi dan ditampilkan dalam bentuk tabel ataupub grafik dengan menggunakan bantuan Software Excell dan SPSS .

Selanjutnya untuk mendapatkan peringkat dalam setiap variabel penelitian dapat dilihat dari perbandingan antara skor aktual dengan skor ideal. Skor ideal diperoleh melalui hasil perhitungan seluruh pendapat responden sesuai klasifikasi bobot yang diberikan $(1,2,3,4$, dan 5). Sedangkan skor ideal diperoleh melalui perolehan prediksi nilai tertinggi dikalikan dengan jumlah kuesioner dikalikan jumlah responden.

Analisis Kuantitatif : Analisis digunakan untuk mengukur kedua variabel antara Pengendalian Internal dan Pencegahan Kecurangan (fraud) Kas. Data kuantitatif bisa didapar melalui analisis korelasi untuk mengetahui pengaruh dua variabel yang diteliti apakah terdapat pengaruh atau tidaknya dan seberapa kuat pengaruh kedua variabel tersebut. Pada analisis kuantitatif akan menggunakan korelasi sederhana yaitu analisis korelasi
Pearson dikarenakan variabel yang diteliti hanya berjumlah dua variabel, oleh sebab itu peneliti menggunakan analisis korelasi sederhana.Mengingat peneliti menggunakan korelasi pearson yang mensyaratkan data berbentuk interval, sedangkan data dalam penelitian berbentuk Ordinal, maka perlu dilakukan transformasi data menggunakan Method Succesive Interval. Selanjutnya dicari kontribusi variabel bebas terhadap variabel terikat dengan menggunakan Koefisien Determinasi.

\section{HASIL DAN PEMBAHASAN}

\section{Analisis Kualitatif :}

Tanggapan Responden tentang :Pengendalian Internal di PT. Bank Mandiri (Persero), Tbk Area Asia Afrika sebagai berikut :

Pengendalian internal yang dilakukan di PT. Bank Mandiri (Persero), Tbk Area Asia Afrika Bandung sudah baik. Pegawai sudah memiliki etika dan integritas yang baik. Bank juga memiliki struktur organisasi yang jelas dan ada dokumentasinya yang lengkap dengan tugas dan wewenang masingmasing bagian. PT. Bank Mandiri (Persero), Tbk mewajibkan selalu dilakukan cross check di akhir hari dengan karyawan lain. Minimal satu bulan sekali wajib dilakukan cross opname dengan cabang lain dan dibuat berita acara. Masing-masing frontliners diberikan user ID dan password masing-masing, dan tidak diperbolehkan untuk sharing password. Pengontrolan yang dilakukan pada saat transaksi diatas limit harus meminta password ke bagian yang lebih tinggi. Setiap transaksi diwajibkan harus ada bukti transaksi, tanda tangan dari nasabah yang bersangkutan. Laporan 
transaksi diakhir hari harus diketahui oleh pimpinan cabang atau Branch Manager.

\section{Variabel}

independent

(Pengendalian Internal) diperoleh melalui perhitungan persentase terhadap skor jawaban responden. Skor tersebut diperoleh dengan memberikan angket yang berisi pertanyaan tentang Pengendalian Internal dan Pencegahan Kecurangan (fraud) Kas. Pertanyaan yang mewakili Variabel Independent (Pengendalian Internal) adalah nomor 1 sampai dengan nomor 15. Penilaian tanggapan terhadap Variabel Independent (Pengendalian Internal) dapat dihitung dengan rumus sebagai berikut:

Skor Total $=\frac{\text { Skor Aktual }}{\text { Skor Ideal }} \times 100 \%$

Keterangan :

Skor Aktual = Jawaban

Seluruh Responden

Skor Ideal = Jawaban

Seluruh Responden yang diasumsikan memilih

Tertinggi
Jawaban

Tabel 1 Kriteria Persentasi Skor Tanggapan Responden Terhadap Skor Ideal

\begin{tabular}{ccc}
\hline No. & Jumlah Skor $(\%)$ & Kriteria \\
\hline 1 & $20,00-36,00$ & Tidak Baik \\
2 & $36,01-52,00$ & Kurang Baik \\
3 & $52,01-68,00$ & Cukup \\
4 & $68,01-84,00$ & Baik \\
5 & $84,01-100$ & Sangat Baik \\
\hline
\end{tabular}

Catatan : Batas bawah 20\% diperoleh dari 1/5, dan batas atas $100 \%$ dari $5 / 5$ Sumber: Umi Nariwati (2007 : 85)

Perhitungan :

$\begin{aligned} \text { Skor Total } & =\frac{1817}{2250} \times 100 \% \\ & =81 \%\end{aligned}$

Responden memberi tanggapan kepada seluruh Variabel Independen (Pengendalian Internal) yaitu sebanyak $81 \%$. Berdasarkan tabel skor, angka tersebut berada di kategori Baik.

\section{Tanggapan}

Responden

Pencegahan Kecurangan (Fraud) Kas di PT. Bank Mandiri (Persero), Tbk Area Asia Afrika Berdasarkan Pencegahan kecurangan (fraud) kas yang diterapkan sudah cukup baik. PT. Bank Mandiri (Persero), Tbk menerapkan program reading discussion yang membahas mengenai control atau tentang tindakan kecurangan (fraud) minimal satu minggu sekali sehingga diharapkan seluruh karyawan dapat memahami mengenai peraturan-peraturan yang berlaku, yang seharusnya dilakukan sesuai dengan prosedur. PT. Bank Mandiri (Persero), Tbk juga memiliki 5 nilai budaya dan 11 prilaku utama insan Bank Mandiri, dimana salah satu poinnya berbunyi "Trust - Jujur, Tulus, Terbuka dan Tidak Sungkan". Diharapkan pegawai dapat memahami akan arti poin tersebut dan mampu untuk mengimplementasikannya. Selain 
itu antar pegawai harus saling mengenal satu sama lain, sehingga apabila ada sesuatu yang tidak biasa pada sikap seseorang maka mampu saling mengingatkan. Setiap pegawai yang berani melakukan tindakan kecurangan (fraud) kas, PT. Bank Mandiri (Perseor), Tbk akan memberikan sanksi yang setimpal.

Variabel Dependent (Pencegahan Kecurangan (Fraud) Kas)

$$
\text { Skor Total }=\frac{\text { Skor Aktual }}{\text { Skor Ideal }} \times 100 \%
$$

Keterangan :

Skor Aktual

Skor Ideal

Perhitungan :

$$
\begin{aligned}
= & \text { Jawaban Seluruh Responden } \\
= & \text { Jawaban Seluruh Responden yang diasumsikan memilih } \\
& \text { Jawaban Tertinggi }
\end{aligned}
$$

$$
\text { Skor Total }=\frac{1492}{2250} \times 100 \%
$$$$
=66 \%
$$

Responden memberi tanggapan kepada seluruh Variabel Dependen (Pencegahan Kecurangan (Fraud) Kas) yaitu sebanyak 66\%. Angka tersebut berdasarkan tabel skor berada pada kategori cukup.

\section{Analisis Kuatitatif :}

\section{Korelasi :}

Untuk mengetahui hubungan Berikut ini adalah hasil antara Pengendalian Internal dengan pengolahan Software SPSS 20.0 untuk Pencagahan Kecurangan (Fraud) Kas, koefisien korelasi Pengendalian Internal digunakan analisis korelasi pearson. dengan Pencegahan Kecurangan (Fraud) Kas. 
Tabel 2 Analisis Korelasi Pearson

Correlations

\begin{tabular}{|c|c|c|c|}
\hline \multirow{3}{*}{ Pengendalian } & & Pengendalian & Kecurangan \\
\hline & $\begin{array}{l}\text { Pearson } \\
\text { Correlation }\end{array}$ & 1 &, $776^{\star \star}$ \\
\hline & $\begin{array}{l}\text { Sig. }(2- \\
\text { tailed) }\end{array}$ & &, 000 \\
\hline \multirow{3}{*}{ Kecurangan } & $\mathrm{N}$ & 30 & 30 \\
\hline & $\begin{array}{l}\text { Pearson } \\
\text { Correlation }\end{array}$ &, $776^{* *}$ & 1 \\
\hline & $\begin{array}{l}\text { Sig. (2- } \\
\text { tailed) }\end{array}$ & ,000 & \\
\hline \multicolumn{4}{|c|}{ 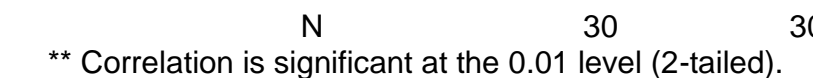 } \\
\hline
\end{tabular}

Berdasarkan tabel diatas diperoleh nilai koefisien korelasi (r) sebesar 0,776, yang berarti terdapat hubungan korelasi yang kuat antara pengendalian internal dengan pencegahan kecurangan (fraud) kas.

Koefisien Determinasi :

Beberapa pengaruh Pengendalian Internal terhadap Pencegahan Kecurangan (Fraud) Kas, ditunjukan oleh koefisien determinasi dengan rumus sebagai berikut:

$K D=r^{2} \times 100 \%=$
$(0,776)^{2} \times 100 \%$

$$
Y=a+b X
$$

Keterangan : $\mathrm{Y}=$ Pencegahan Kecurangan $($ Fraud $)$ Kas

$\mathrm{X}=$ Pengendalian Internal

$\mathrm{a}=$ Konstanta

$\mathrm{b}=$ Koefisien Regresi

Berdasarkan hasil pengolahan data menggunakan bantuan Software SPSS diperoleh hasil sebagai berikut: 
Tabel 3 Analisis Regresi Linear Sederhana

Coefficients $^{a}$

\begin{tabular}{|c|c|c|c|c|c|}
\hline Model & $\begin{array}{l}\text { Unstan } \\
\text { Coeff }\end{array}$ & $\begin{array}{l}\text { irdized } \\
\text { ents }\end{array}$ & $\begin{array}{c}\text { Standardized } \\
\text { Coefficients }\end{array}$ & $\mathrm{T}$ & Sig. \\
\hline (Constant) & $\begin{array}{l}\mathrm{B} \\
1,860\end{array}$ & $\begin{array}{l}\text { Std. Error } \\
4,374\end{array}$ & Beta & ,425 & 674 \\
\hline Pengendalian & ,640 & 098, & ,776 & 6,501 &, 000 \\
\hline
\end{tabular}

a. Dependent Variable: Kecurangan

Dari output Software SPSS 20.0 diatas diperoleh model regresi sebagai

\begin{abstract}
berikut:
$Y=1,860+0,640 X$

Nilai konstanta a memiliki arti bahwa ketika Pengendalian Internal (X) bernilai nol atau Pencegahan Kecurangan (Fraud) Kas (Y) tidak dipengaruhi oleh Pengendalian Internal, maka rata-rata Pencegahan Kecurangan (Fraud) Kas bernilai 1,860, sedangkan koefisien regresi $b$ memiliki arti bahwa jika variabel Pengendalian Internal (X)
\end{abstract}

\section{SIMPULAN}

Berdasarkan hasil pembahasan, maka dapat disimpulkan bahwa Pengendalian Internal memiliki pengaruh yang signifikan terhadap Pencegahan Kecurangan (Fraud) Kas pada PT. Bank Mandiri (Persero), Tbk Area Asia Afrika. Adapun hal-hal yang mendukung simpulan tersebut adalah sebagai berikut:

1. Secara umum pengendalian internal yang dilaksanakan PT. Bank Mandiri (Persero), Tbk Area Asia Afrika sudah baik. Hal tesebut dapat dilihat dari indikator pengendalian internal yang terdiri dari lingkungan pengendalian, penilaian risiko, aktivitas pengendalian, informasi dan komunikasi serta pengawasan, dengan meningkat satu satuan, maka Pencegahan Kecurangan (Fraud) Kas akan meningkat 0,640. Koefisien regresi tersebut bernilai positif, yang artinga Pengendalian Internal memberikan pengaruh positif terhadap Pencegahan Kecurangan (Fraud) Kas (semakin tinggi/kuat Pengendalian Internal, maka semakin meningkat Pencegahan Kecurangan (Fraud) Kas). hasil perhitungan yang diperoleh tanggapan dari responden sebesar $81 \%$.

2. Secara umum pelaksanaan pencegahan kecurangan (fraud) kas yang dilaksanakan PT. Bank Mandiri (Persero), Tbk Area Asia Afrika sudah cukup. Hal ini dapat dilihat indikator pencegahan kecurangan (fraud) kas yang terdiri dari menciptakan kejujuran, keterbukaan dan saling membantu, proses rekruitmen pegawai yang jujur, pelatihan fraud awareness, lingkup kerja yang positif, kode etik yang jelas, mudah dimengerti dan ditaati, program bantuan kepada pegawai yang mengalami kesulitan, serta sanksi terhadap segala jenis tindakan kecurangan (fraud) , dengan hasil perhitungan yang diperoleh dari tanggapan responden sebesar $66 \%$.

3. Pengendalian Internal memberikan pengaruh sebesar $60,2 \%$ 
sedangkan sisanya sebesar $39,8 \%$ dipengaruhi oleh variabel lain yang tidak diteliti. 


\section{DAFTAR PUSTAKA}

Krismiaji. 2002, Sistem Informasi Akuntansi. Yogyakarta: UPP AMP YKPN

Azhar Susanto, 2009, Sistem Informasi Akuntansi, Lingga Jaya, Jakarta.

Lawrence Sawyer B, Mortimer A, Dittenhofer, 2008, Sawyer Internal Auditing,

Dialihbahasakan oleh: Ali Akbar,

2008, Audit Internal Sawyers, Edisi

Lima, Salemba Empat, Jakarta.

Mulyadi, 2008, Sistem Informasi Akuntansi,

Salemba Empat, Jakarta.

Jerry L. Turner, Theodore J. Mock, dan Rajendra P. Srivasta 2003, An

Analysis Of The Fraud

Kumaat, Valery G.. 2010, Internal Audit., Erlangga: Jakarta.

Azhar Susanto, 2009, Sistem Informasi Akuntansi, Lingga Jaya, Jakarta.

Sugiyono, 2009, Metode Penelitian Bisnis, Cetakan Kesebelas, CV. Alfabeta,

Bandung,

Pusdiklatwas BPKP, 2008a, Kode Erik dan Standar Auditing Pusdiklatwas BPKP, 2008b, Reviu Ketas Kerja Audit 